\title{
КОМПАРАТИВНИЙ АНАЛІЗ ПОДАТКОВОГО ЗАБЕЗПЕЧЕННЯ ЕКОНОМІЧНОЇ СТАБІЛЬНОСТІ ТА ВИЗНАЧЕНОСТІ: УКРАЇНА VS НIМЕЧЧИНА
}

\author{
Потапенко Денис Олександрович, \\ кандидат економічних наук, \\ дочент кафедри теоретичної та прикладної економіки, \\ ВН3 «Університет економіки та права «КРОК», \\ ORCID: https://orcid.org/0000-0002-4401-9243,
}

Троц Ірина Вікторівна, кандидат економічних наук, дочент кафедри теоретичної та прикладної економіки, ВН3 «Університет економіки та права «КРОК», ORCID: https://orcid.org/0000-0001-9608-0591

Aнотація. Податки можуть ставати визначальним інструментів впливу на стабільність та визначеність національної економіки. Але за одних умов вони стабілізують, а за інших, навпаки, - руйнують стабільність. У цьому розділі, спираючись на порівняння двох національних моделей оподаткування - успішної німецької та неуспішної української автори намагаються зробити певні узагальнення. Вони стосуються відповідей на питання: у який спосіб можна через податкову систему створювати умови стабільної економічної діяльності та обмежувати економічну невизначеність.

Ключові слова: податкова система, податкове навантаження, податковий тягар, податкові пільги та субсидії, податкова стабільність.

Актуальність теми впливу на стабільність економіки через систему оподаткування є незаперечною. Суб'єкти української економіки зазнають різні суперечливі впливи від фінансових установ, які не виконують функцій доступного кредитування, від монетарної сфери 3 іiі змінами курсу національної валюти, від судової системи, яка не захищає права власності тощо. Але найбільш суттєвий вплив на економічну діяльність усе ж справляють податки. Під «податковим забезпеченням стабільності економіки» маємо на увазі не лише сукупність певних видів податків та податкових ставок. Ідеться про способи стягнення податків, пріоритети органів податкової влади, незмінність і прозорість правил стягнення податків тощо.

За майже 30 років існування новітньої Української держави податкова система зазнавала перманентних змін. Але попри ці зміни, здійснювані під «благородними політичними гаслами», податкові органи, здебільшого, виконували фіскальні та каральні функції. Натомість, 
український бізнес потребував стимулюючих, консультативних функцій та функцій упорядкування. Брак останніх підривав стабільність економіки й продовжує стримувати їі розвиток на початку 2020-х рр. У період найважчої, за масштабами згортання українського бізнесу, економічної кризи 2019 - 2020 рр. реформування податкової системи набуває ще більшої ваги. Метою цього реформування, на думку авторів розділу, має стати передусім порятунок українського малого та середнього бізнесу, стимулювання сукупного попиту споживачів. Тому порівняння української практики оподаткування з практикою найбільш розвиненої країни Свропейського Союзу - Німеччини може сприяти обгрунтуванню раціональних і доцільних рішень у сфері публічного управління.

Вплив податків на стабільність економіки є предметом багатьох досліджень аналітиків 3 різних країн $[1 ; 2]$. Вплив податкового навантаження на розвиток бізнесу аналізується й українськими дослідниками [3; 4].

Ми робимо припущення про існування такого алгоритму переходу імпульсу від податкової системи до економічної стабільності та економічної визначеності/невизначеності (рис. 1).

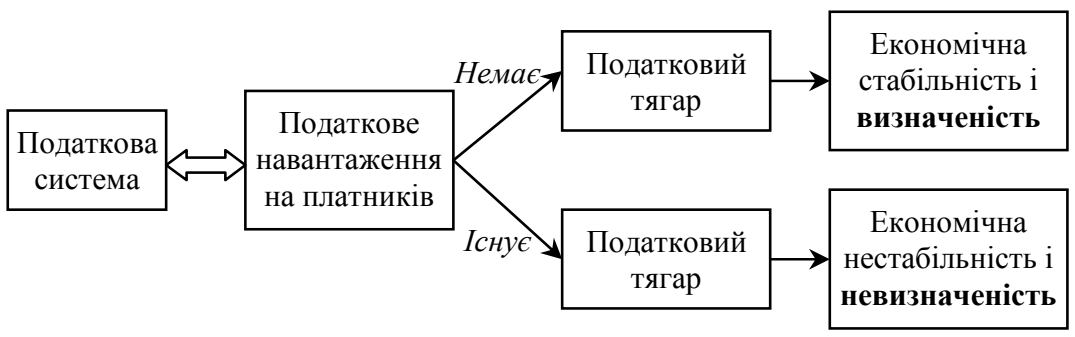

Рис. 1. Алгоритм переходу імпульсу від податкової системи до економічної визначеності/невизначеності

Джерело: розроблено авторами самостійно.

На рисунку ілюстровано ідею формування податковою системою стану економічної визначеності або, навпаки, невизначеності за участі таких передавальних елементів, як податкове навантаження та податковий тягар. За наявності податкового тягаря і за його збільшення створюється економічна невизначеність. Натомість, за відсутності та зменшення податкового тягаря формується економічна визначеність.

У пропонованій теоретичній конструкції (рис. 1) у поняття «податкове навантаження» $\mathrm{i}$ «податковий тягар» вкладається такий зміст.

Податкове навантаження $є$ віддзеркаленням частки сукупних доходів (ВВП), перерозподілених через бюджет у формі податків $(T / Y)$. Оскільки зв'язок між податками та доходами (ВВП) не є лінійним, 
остільки податкові надходження досягають оптимуму лише за певних значень доходів (ВВП).

Податковим тягарем стає надмірне (надлишкове) податкове навантаження. Його (навантаження) надмірність (надлишковість) виявляється принаймні у тому, що після певної межі подальший приріст $(\Delta)$ навантаження може спричиняти такі наслідки:

- гальмувати економічне зростання через втрату підприємницького інтересу до діяльності та через обмеження власного інвестиційного потенціалу підприємств;

- недовіру до влади через порушення принципів соціальної справедливості та несприйняття ії̈ економічних стимулів;

- збільшення необгрунтованих витрат у зв'язку з ускладненням бюрократичних процедур;

- зростання масштабів тіньової економіки через приховування фактичних доходів та ділових операцій.

За пропонованою авторами логікою міркувань, податкове навантаження, яке не містить в собі частини $(\Delta)$ у вигляді податкового тягаря, формує економічну визначеність.

Цінність висновків на підставі порівняння податкових систем двох країн - України та Німеччини - може ставитися під сумнів. Адже країни мають суттєво відмінні економічні потенціали. Це, зокрема, ілюструють дані табл. 1.

За інформацією, поданою у табл. 1, економічний потенціал двох країн суттєво відрізняється за такими параметрами:

- за масштабами створюваного ВВП: у Німеччині ВВП більший у 8,3 разів (у дол. еквіваленті з урахуванням ПКС);

- за загальним рівнем добробуту: ВВП на душу населення в Німеччині перевищує подібний показник в Україні у 4,2 рази;

- за рівнем макроекономічної стабільності: темп інфляції вищий в українській економіці, приблизно, в 4 рази, а рівень безробіття помітно перевищував природний показник та був більшим, ніж у Німеччині, у 2,7 рази;

- за рівнем зовнішньої економічної та фінансової стабільності: в Україні, на відміну від Німеччини, було від'ємне сальдо рахунку поточних операцій, від'ємне сальдо торгового балансу, висока залежність від імпорту енергоносіїв, майже в 10 разів менші обсяги офіційних валютних резервів;

- за рівнем інноваційності економіки: частка інноваційної продукції в експорті України була в 3 рази меншою, ніж у Німеччині [5]. 
Таблиия 1

Показники економічного потенціалу Німеччини та України у 2019 р.

\begin{tabular}{|l|c|c|c|}
\hline \multicolumn{1}{|c|}{ Показник } & $\begin{array}{c}\text { Одиниця } \\
\text { виміру }\end{array}$ & Німеччина & Україна \\
\hline $\begin{array}{l}\text { ВВП за паритетом купівельної } \\
\text { спроможності (ПКС) }\end{array}$ & $\begin{array}{c}\text { млрд міжнар. } \\
\text { дол. }\end{array}$ & 4672,01 & 560,98 \\
\hline ВВП по ПКС на душу населення & міжнар. дол. & 56226 & 13442 \\
\hline Iндекс споживчих цін & $\%$ & $1,3 \%$ & $7,9 \%$ \\
\hline Рівень безробіття & $\%$ & $3,1 \%$ & $8,5 \%$ \\
\hline $\begin{array}{l}\text { Баланс рахунку поточних операцій, } \\
\text { дол. США }\end{array}$ & $\begin{array}{c}\text { млрд дол. } \\
\text { США }\end{array}$ & 273,2 & $-4,2$ \\
\hline $\begin{array}{l}\text { Баланс рахунку поточних операцій, } \\
\text { \% до ВВП }\end{array}$ & \% & 7,1 & $-2,7$ \\
\hline Міжнародні резерви & млрд дол. США & 224 & 25 \\
\hline Експорт товарів & млрд дол. США & 1464 & 46 \\
\hline Експорт послуг & млрд дол. США & 347 & 17 \\
\hline Експорт високотехнологічних товарів & млрд дол. США & 207 & 1 \\
\hline $\begin{array}{l}\text { Експорт високотехнологічних } \\
\text { товарів у \% від експорту товарів }\end{array}$ & \% & 16,4 & 5,4 \\
\hline Імпорт товарів і послуг & млрд дол. США & 1588 & 76 \\
\hline Імпорт товарів & млрд дол. США & 1217 & 60 \\
\hline Імпорт послуг & млрд дол. США & 371 & 16 \\
\hline Імпорт продовольства & \% & 7,8 & 8,6 \\
\hline $\begin{array}{l}\text { Імпорт паливно-енергетичних у \% від } \\
\text { імпорту товарів }\end{array}$ & \% & 8,5 & 23,5 \\
\hline Експорт товарів & млн дол. США & 1489152 & 50066 \\
\hline Імпорт товарів & млн дол. США & 1234454 & 60607 \\
\hline
\end{tabular}

Джерело: розроблено авторами на основі [6; 7].

Визнаючи факт суттєвих відмінностей економічних потенціалів двох країн, однак, не можна ігнорувати таке.

По-перше, є підстави для припущення, що нерелевантність невідповідність об'єктивним потребам економіки та суспільства української податкової системи саме й стає однією з основних причин суттєвих відмінностей потенціалів.

По-друге, в Конституції України зафіксовано вектор руху в бік ЄC - унії, в якій Німеччина посідає провідне місце. Тому економіка та система публічного управління в цій країні об'єктивно мають розглядатися як певний орієнтир для України.

По-третє, Німеччина $є$ важливим торговельним партнером України. До прикладу, за результатами 2019 року Німеччина посіла перше місце серед торговельних партнерів України у Свропі з часткою у 17,31\% від загального товарообігу. Обсяг цього товарообігу становив 9,4 млрд дол. США. Важливо й те, що прирости українського експорту 
до Німеччини в цей рік були більшими, ніж прирости імпорту України 3 Німеччини.

По-четверте, між країнами існує рух інвестицій. Попри те, що інвестиційні потоки не є значними за обсягами, важливими є власне напрямки інвестування. Частка Німеччини в залучених в Україну прямих іноземних інвестиціях у 2019 р. становила 5,16\%. Обсяг інвестицій досягнув 1668,1 млн дол. США. Німеччина посідає четверте місце в переліку іноземних інвесторів України. При цьому левова частка (62\%) німецьких інвестицій спрямовувалася в українську промисловість. Другим, за часткою німецьких інвестицій, був напрямок оптової та роздрібної торгівлі й ремонту автотранспортних засобів (12,5\%), третім - транспорт, складське господарство, поштова та кур'єрська діяльність (8\%). Прямі інвестиції з України до Німеччини у 2019 р. склали 3,42 млн дол. США, причому, 3 них 72,8\% спрямовані у переробну промисловість [8].

Враховуючи зазначені факти економічної взаємодії двох країн, порівняння податкових систем України та Німеччини не позбавлене сенсу та певної наукової цінності.

Власне порівняння української і німецької податкових систем може спиратися на міжнародний рейтинг «Doing Business» від Світового банку. Адже при його створенні беруться до уваги параметри податкових систем країн. Дані для порівняння подано у табл. 2.

Табличя 2

Характеристики податкових систем Німеччини та України у 2020 р., за рейтингом «Doing Business»

\begin{tabular}{|l|c|c|}
\hline \multicolumn{1}{|c|}{ Показник } & Німеччина & Україна \\
\hline Рейтинг оподаткування & 46 & 65 \\
\hline Платежі (кількість у рік) & 9,0 & 5,0 \\
\hline Час (години в рік) & 218 & 328 \\
\hline Загальна ставка податків і зборів (\% від доходів) & 48,8 & 45,2 \\
\hline $\begin{array}{l}\text { Індекс процедур після подачі звітності та сплати } \\
\text { податків (0-100) }\end{array}$ & 97,7 & 86,0 \\
\hline
\end{tabular}

Джерело: розроблено авторами на основі [9].

Інформація, подана у табл. 2, свідчить про таке:

- українська податкова система на 19 позицій рейтингу оцінюється як гірша, ніж німецька;

- податкове навантаження, як \% доходів, сплачених у вигляді податків та зборів у двох країнах, суттєво не відрізняється, і навіть у Німеччині воно є дещо вищим, ніж в Україні $(48,8>45,2)$;

- процедура сплати податків у Німеччині є простішою, оскільки передбачає менші витрати часу на облік та виконання процедур (218 
годин < 328 годин), а загальний індекс процедур у Німеччині є кращим, ніж в Україні.

3 огляду на відмінності у податкових системах країн та на інші відмінності умов підприємницької діяльності, місце України та Німеччини за рейтингом привабливості провадження бізнесу впродовж 2006 2020 рр. було таким (рис. 2).

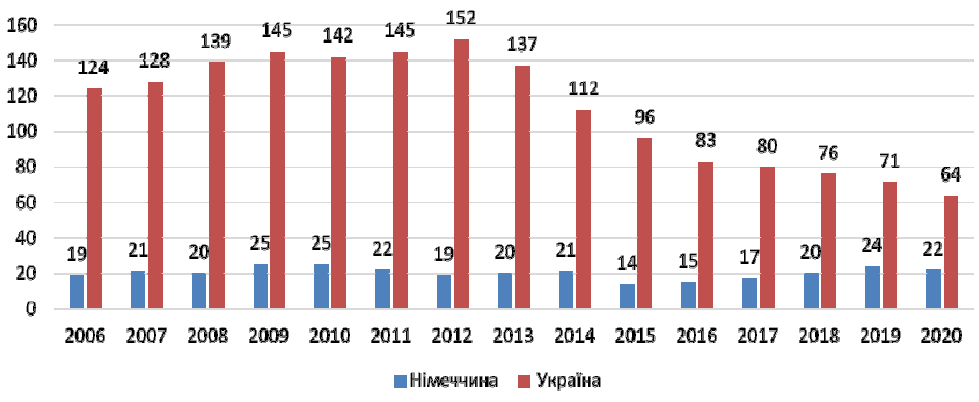

Рис. 2. Рейтинги Німеччини та України, за індексом легкості провадження бізнесу - «Doing Business», y 2006 - 2020 pp. Джерело: розроблено авторами на основі [9].

За інформаціє, поданою у табл. 2 та на рис. 2, Німеччина не $\epsilon$ світовим лідером за якістю податкової системи, перебуваючи у п’ятій десятці країн. Так само країна не є лідером за критерієм легкості ведення бізнесу, часто посідаючи місце лише у третій десятці країн. Але місце Німеччини в рейтингу легкості провадження бізнесу за аналізований період змінювалося несуттєво. Його середнє значення формувалося на рівні 20-ої позиції. Це можна тлумачити як свідчення відносної стабільності та досягнутої економічної визначеності. Натомість, рейтинг України змінювався суттєво, сягнувши найгіршої позиції (152 місце) у 2012 р. і найкращої (64 місце) - у 2020 р. Показовим є стрімке покращання позиції в рейтингу легкості провадження бізнесу після 2013 p.

Принципово важливою при порівнянні податкових систем країн стає ідентифікація основних «бюджетоутворюючих» податків. Інформація про частки податкових надходжень за окремими видами податків у бюджетах двох країн подано на рис. 3 та рис. 4.

Інформація, подана на рис. 3, свідчить про те, що податкова система Німеччини побудована у такий спосіб, що основним «бюджетоутворюючим» податком у ній є податок на доходи громадян $(27,48 \%)$. 


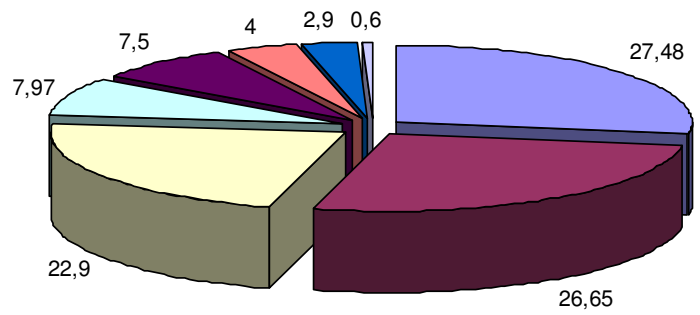

口1. Податок на доходи громадян - $27,48 \%$

口2. Інші (федеральні та окремих земель) податки і збори - 26,65\%

口3. Податок на додану вартість - $22,9 \%$

口4. Податок на прибуток підприємств - 7,97\%

घ. Податок з продажу на імпорт - $7,5 \%$

口6. Корпоративний податок - $4 \%$

口7. Інші податки на доходи - $2,9 \%$

口8. Податки на дивіденди з відсотків на приріст капіталу - 0,6\%

\section{Рис. 3. Структура податкових надходжень до бюджету Німеччини} у 2019 p., \%

Джерело: розроблено авторами на основі [10].

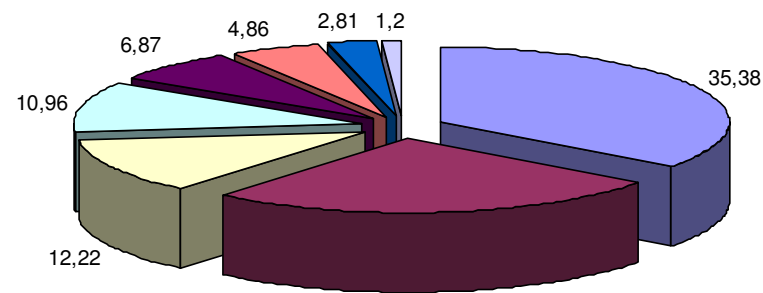

25,7

⒈ Податок на додану вартість - 35,38\%

๑2. Податок на доходи фізичних осіб - $25,7 \%$

口 3. Акцизний податок - $12,22 \%$

$\square$ 4. Податок на прибуток підприємств - 10,96\%

— 5. Місцеві податки та збори, включно з єдиним соціальним податком - 6, 87\%

๑ 6. Рентна плата та плата за використання інших природних ресурсів - 4,86\%

๑ 7. Податки на міжнародну торгівлю та зовнішні операції - $2,81 \%$

๑ 8. Інші податки та збори - 1,2\%

Рис. 4. Структура податкових надходжень до бюджету України y 2019 p., \%

Джерело: розроблено авторами на основі [11].

Інформація 3 рис. 4 дає підстави для висновку, що основним «бюджетоутворюючим» податком, за української податкової системи, 
$\epsilon$ податок на додану вартість (35,38\%). Цей факт лише підтверджує зафіксовану на прикладі багатьох країн закономірність: бюджети у країнах з нижчим рівнем економічного розвитку, здебільшого, формуються за рахунок непрямих податків. До останніх, як відомо, належить i ПДВ. Натомість, у країнах з вищим рівнем розвитку переважаючими у формуванні бюджетів є прямі податки, зокрема податки на доходи фізичних осіб.

Окрім зазначеної відмінності, пов'язаної з різними основними «бюджетоутворюючими» податками, порівняння дає можливість ідентифікувати ще й інші відмінності. Ми акцентуємо увагу лише на тих, які є важливими для розуміння стабілізуючого впливу податків. До таких відмінностей, зокрема, належить і те, що:

- в українській податковій системі не виокремлюється корпоративний податок, що, з огляду на олігархічну модель української економіки та пов'язаність олігархів 3 великими корпораціями (монополіями), є неприродним;

- суттєво різною є частка місцевих податків, відтак, і можливості місцевих бюджетів в Україні є суттєво іншими.

Податкова система Німеччини характеризується стягненням податків на трьох рівнях: загальному (центральному), федеральному та окремих земель. Для усвідомлення іï особливостей і стабілізуючого впливу важливо брати до уваги, як розподілено податки за рівнями (табл. 3).

Таблиця 3

\section{Розподіл податків за рівнями у податковій системі Німеччини}

\begin{tabular}{|c|c|c|}
\hline $\begin{array}{l}\text { Загальні податки - } \\
\text { Gemeinschaftsteuern }\end{array}$ & $\begin{array}{c}\text { Федеральні податки - } \\
\text { Bundessteuern }\end{array}$ & $\begin{array}{c}\text { Податки окремих } \\
\text { земель - Landessteuern }\end{array}$ \\
\hline $\begin{array}{l}\text { - податок на доходи; } \\
\text { - податок на прибуток } \\
\text { підприємств; } \\
\text { - корпоративний } \\
\text { податок; } \\
\text { - податки з продажів, } \\
\text { включно з податком на } \\
\text { додану вартість (ПДВ); } \\
\text { - податки на торгівлю }\end{array}$ & $\begin{array}{l}\text { - податок на енергію; } \\
\text { - податок на тютюн; } \\
\text { - податки на алкоголь, } \\
\text { бренді, вина; } \\
\text { - податок на каву; } \\
\text { - проміжний податок на } \\
\text { товар; } \\
\text { - страховий податок; } \\
\text { - податок на автотранспортні } \\
\text { засоби; } \\
\text { - авіаційний податок }\end{array}$ & $\begin{array}{l}\text { - податок на багатство; } \\
\text { - податок на землю; } \\
\text { - податок на спадок; } \\
\text { - податок на купівлю } \\
\text { землі; } \\
\text { - податок на пиво; } \\
\text { - податок на азартні ігри }\end{array}$ \\
\hline
\end{tabular}

Джерело: розроблено авторами на основі [10].

На основі інформації, поданої в табл. 3, можна робити висновок принаймні про більш різноманітний перелік податків, що збираються на рівні федеральних утворень та окремих земель у Німеччині.

Стрижень стабілізуючого впливу податкової системи пов'язаний 3 формуванням податкових ставок за окремими податками і з податковими пільгами. Їх дослідження дає підстави для висновків про спрямованість 
та пріоритети і податкової системи, і всієї публічної влади. Тому ми розглядаємо ставки та пільги саме під кутом зору тих пріоритетів, на досягнення яких вони можуть бути спрямовані [12-15].

Пріоритет соиіальної стабільності й обмеження нерівності розподілу багатства виявляється у таких особливостях податкової системи Німеччини:

- прогресивному оподаткуванні доходів громадян 3 диференціацією ставок від $14 \%$ до $45 \%$, при неоподаткованому річному мінімумі доходів у 8,82 тис. євро та найбільшій податковій ставці у 42\%, що застосовується до доходів, які перевищують річний обсяг у 53,6 тис. євро;

- неоподаткованій щомісячній зарплаті малозабезпечених родин у вигляді: зменшення бази оподаткування для неповних родини з дітьми (на 1077 С), а також для родин, де один з ії членів втратив роботу (на 945 євро) тощо;

- застосуванні зменшеної - на рівні 7\% - ставки податку на додану вартість (ПДВ) для продуктів харчування (овочів, фруктів, молочних виробів, борошна та круп), а також для книжок і газет, на противагу загальній податковій ставці у 19\% для всіх інших товарів;

- виокремленні двох груп платників податку на доходи фізичних осіб: 1) осіб самостійного працевлаштування, що створюють робочі місця - індивідуальних підприємців, фрілансерів, адвокатів, податкових консультантів, лікарів, якщо у них є власна практика (Einkommensteuer), 2) найманих працівників та чиновників (Lohnsteuer);

- зменшенні бази оподаткування на величину, так званих «витрат, пов'язаних з отриманням доходу» (Werbungskosten), до яких належать витрати на переїзди до місця роботи, а також ті, що пов'язані зі зміною місця роботи при їі втраті;

- прогресивному податку на дарування та успадкування 3 диференціацією ставок від 7\% до 50\% й у встановленні межі у 75 тис. євро для застосування мінімальної ставки;

- вищому, ніж при сплаті податку на прибуток, рівні податку на дивіденди (ставка 25\%) та вищому рівні податку на приріст доходів і капіталу, отриманих при продажах цінних паперів (ставка 26,375\%);

- фактичній сплаті податку на багатство при придбанні будьякої нерухомості на території країни з диференційованою ставкою від $3,5 \%$ до $5 \%$.

Пріоритет підтримки невеликих підпиємств, що має такі прояви:

- стандартна ставка корпоративного податку на прибуток становить $15 \%$ та збільшується для корпорацій на 5,5\%, так званого податку «на солідарність» для підтримки приєднаних (Східних німецьких) земель;

- базовою для некорпоративних підприємств є ставка 3,5\%, яка коригується на коєфіцієнт, встановлений окремо для кожного муніципалітету; 
- за податковими ставками, що коливаються в межах від 14 до $17,15 \%$, сплачуються податки підприємствами, прибуток яких перевищує 24,5 тис. євро;

- ставка податку на прибуток може встановлюватися індивідуально місцевими податковими органами.

Пріоритет стимулювання експортної діяльності, передусім за межами $\mathrm{CC}$, реалізується у такий спосіб:

- не оподатковується податком на продаж операції з постачання товарів та послуг за межі СС, а також авіаційні та морські перевезення.

Пріоритет реагування на актуальні загрози для економіки та суспільства забезпечується, зокрема, так:

- для подолання економічних наслідків Covid-19 уряд Німеччини знизив загальну ставку ПДВ з 19\% до 16\%, а пільгову ставку на продукти харчування - 3 7\% до 5\%.

Пріоритет підтримки фермерства та екологічного виробництва у вигляді «антиподатків» - субсидій та субвенцій - втілюється у таких діях:

- використанні урядом Німеччини коштів зі спільних фондів СС (до прикладу, 58 млрд євро у 2017 р.) на спеціальну підтримку виробників сільськогосподарської продукції. Зокрема, такими фондами є Свропейський сільськогосподарський гарантійний фонд (EAGF) та Свропейський сільськогосподарський фонд розвитку сільських районів (EAFRD). Частка Німеччини в обсязі 6,5 млрд євро становить 11,2\% від обсягу фондів ЄC [16]. Вона розподіляється урядом Німеччини між фермерами 3 урахуванням таких обставин: 1) масштаб підприємства (кількість га землі на господарство), 2) рівня розвитку регіону, в якому працює господарство, 3) природно-кліматичних та екологічних умов господарювання;

- додатковій підтримці фермерським господарствам на структурну перебудову, екологічні технології тощо від федерального уряду Німеччини, зокрема, через фонди ELER-Topf, ELER-Hilfen, ELER-Förderung.

Важливо те, що надання пільг виробникам сільськогосподарської продукції є повністю прозорим процесом. Адже існує відкрита база даних, з якої можна дізнатися, які підприємства Німеччини, коли та в якому обсязі мали підтримку. До прикладу, відомо, що кількість таких отримувачів уже сягнула більше 310 тисяч підприємств.

Важливим моментом порівняння податкових систем країн $є$ дослідження того, який дохід (зарплата) залишається у платника після оподаткування. Цифрова ілюстрація відповіді на це питання 3 використанням реальних ставок сплачуваних податків та співставних баз оподаткування подано у табл. 4 та табл. 5 .

Як свідчить інформація, подана в табл. 4, податкове навантаження на зарплату в Німеччині суттєво (на 8,76 в. п.) відрізняється в бік послаблення для родин 3 дітьми. Воно формується у процесі сплати шістьох податків: податку на дохід, внеску солідарності з приєднаними федеральними землями, відрахувань у пенсійний фонд, відрахувань на 
медичне страхування, відрахувань на страхування на випадок необхідності догляду, відрахувань на страхування на випадок безробіття. Перелік відрахувань засвідчує всебічну й деталізовану за напрямками соціальну захищеність працюючого платника.

Формування зарплати після сплати податків у Німеччині

Таблиия 4

\begin{tabular}{|c|c|c|c|c|c|}
\hline \multirow[t]{2}{*}{ № } & \multirow[t]{2}{*}{ Зарплата та сплачувані податки } & \multicolumn{2}{|c|}{$\begin{array}{c}\text { Особа, що } \\
\text { перебуває у шлюбі }\end{array}$} & \multicolumn{2}{|c|}{$\begin{array}{c}\text { Особа у шлюбі } \\
\text { та } 3 \text { дітьми }\end{array}$} \\
\hline & & євро & $\%$ & євро & $\%$ \\
\hline 1. & $\begin{array}{l}\text { Щомісячна зарплата (брутто) } \\
\text { середньої й, приблизно, тото } \\
\text { доходу програміста-нерезид } \\
\text { країни, за «блакитною карто }\end{array}$ & 5000 & 100 & 5000 & 100 \\
\hline 2 & Податок на дохід & 1023,50 & 20,47 & 36,16 & 12,72 \\
\hline 3 & $\begin{array}{l}\text { Внесо } \\
\text { федер }\end{array}$ & 56,29 & 1,12 & 16,51 & 0,33 \\
\hline 4. & ий фон & 465,00 & 9,30 & 465 & 9,30 \\
\hline 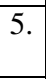 & $\begin{array}{l}\text { Вiдра } \\
\text { страху }\end{array}$ & 389,41 & 7,79 & 389,41 & 7,79 \\
\hline & $\begin{array}{l}\text { Відрахування на страхуван } \\
\text { випадок необхідності догл }\end{array}$ & 67,48 & 1,35 & 56,42 & 1,13 \\
\hline 7. & $\begin{array}{l}\text { Відрахування на страхування на } \\
\text { випадок безробіття }\end{array}$ & 75,00 & 1,50 & 75,00 & 1,50 \\
\hline 8. & $\begin{array}{l}\text { Загальна сума сплачених податків } \\
\text { та відрахувань }\end{array}$ & 2076,68 & 41,53 & 1638,50 & 32,77 \\
\hline & $\begin{array}{l}\text { Щомісячна зарплата (нетто) після } \\
\text { оподаткування }\end{array}$ & 2923,32 & 58,47 & 3361,50 & 67,2 \\
\hline
\end{tabular}

Джерело: розроблено авторами на основі [17].

Таблиия 5

Формування зарплати після сплати податків в Україні у 2020 р.

\begin{tabular}{|c|l|c|c|}
\hline № & \multicolumn{1}{|c|}{ Податок } & грн & $\mathbf{1}$ \\
\hline 1. & $\begin{array}{l}\text { Щомісячна зарплата (брутто), що відповідає середньому } \\
\text { рівню зарплат у великих містах країни у 2020 р. }\end{array}$ & 12000 & 100 \\
\hline 2. & Військовий збір & 180 & 1,5 \\
\hline 3. & Податок з доходів фізичних осіб & 2160 & 18 \\
\hline 4. & $\begin{array}{l}\text { Єдиний соціальний внесок (нараховує і сплачує } \\
\text { роботодавець) }\end{array}$ & 2640 & 22 \\
\hline 5. & Загальна сума сплачених податків та відрахувань & 4980 & 41,5 \\
\hline 6. & Щомісячна зарплата (нетто) після оподаткування & 9660 & $\mathbf{5 8 , 5}$ \\
\hline
\end{tabular}

Джерело: розроблено авторами з використанням офіційних джерел на основі [18; 19].

Інформація, подана у табл. 5, свідчить про податкове навантаження на зарплату українців на рівні пільгового навантаження німецьких родин 3 дітьми. 3 огляду на існування й непільгового оподаткування зарплат, податкове навантаження в Німеччині є дещо вищим, ніж в Україні. 
Українське податкове навантаження на заробітну плату формується 3 використанням трьох податків: військового збору, податку з доходів фізичних осіб, єдиного соціального внеску. Об'єднання платежів із соціального страхування в єдиний податок позбавляє їх (платежі) конкретності й, імовірно, позитивного стимулюючого впливу.

\section{Висновки:}

За результатами порівняння податкових системи України та Німеччини, ми робимо такі висновки:

- українська система оподаткування характеризується існуванням значного податкового тягаря, тому її стабілізуючий потенціал, наразі, не реалізується. Основним підтвердженням цього $€$ те, що при приблизно однаковому податковому навантаженні на доходи та на заробітну плату українська економіка має на порядок гірші показники добробуту, зайнятості, рівня цін, фінансових та зовнішньоекономічних балансів, офіційних валютних резервів тощо. Негативний внесок податкової системи - того, як (у який спосіб) сплачуються податки в Україні - в цьому відставанні за основними економічними та соціальними показниками $\epsilon$ незаперечним;

- 3 огляду на досвід Німеччини, податкова система, яка здатна формувати стабільність та економічну визначеність, повинна мати такі пріоритети:

- формування, 3 використанням податків, стану соціальної справедливості та запобігання необгрунтованій нерівності розподілу доходів і багатства,

- підтримку через податкові ставки та податкові пільги крихкого невеликого бізнесу й фермерських господарств, експортерів вітчизняної продукції,

- швидке реагування на виклики та загрози економіці й суспільству шляхом застосування доцільних механізмів послаблення податкового навантаження у кризових ситуаціях.

\section{Лimepamypa:}

1. Qingwang Guo, Bingyang Lv, Ximing Yue. Regulating Effect of Tax on Chinese National Income Distribution. 1st Edition. 30 September 2020. 274 p.

2. Bing Xu \& Lili Li \& Yan Liang \& Mohib Ur Rahman, Measuring Risk Allocation of Tax Burden for Small and Micro Enterprises. Sustainability, MDPI. 2019. Vol. 11(3). P. 1-20.

3. Alyeksyeyev I., Paranchuk S., Chervinska O. Controlling the tax burden of the enterprise in the reality of ukrainian legislation. Financial sciences nauki o finansach. 2018. Vol. 23. №1. P. 22-32.

4. Radionova I., Boger O. Tax burden and innovation activities: The interrelation problem. Economic Annals-XXI. 2014. №1-2(1). P. 65-69. 
5. Торговельно-економічне співробітництво. Матеріали сайту Посольства України у Федеративній Республіці Німеччина. 22.11.2019. URL : https://germany.mfa.gov.ua/spivrobitnictvo/torgovelno-ekonomichnespivrobitnictvo\#: :text=У\%202019\%20році\%20обсяг\%20торгівлі,склав\% 20близько $\% 209 \% 2 \mathrm{C} 4 \%$.

6. Мировой атлас данных. Германия. Материалы сайта knoema. URL : https://knoema.ru/atlas/Германия.

7. Мировой атлас данных. Украина. Материалы сайта knoema. URL : https://knoema.ru/atlas/Украина.

8. Торговельно-економічне співробітництво між Україною та Німеччиною. Матеріали сайту Посольство України у Федеративній Республіці Німеччина. URL : http://germany.old.mfa.gov.ua/ua/ukrainede/trade.

9. Doing Business. Оценка бизнес регулирования. Материалы Всемирного банка. URL : https://www.doingbusiness.org.

10. Kassenmäßige Steuereinnahmen des Bundes, der Länder und der Gemeinden nach Steuerarten vor der Steuerverteilung in Millionen Euro. Destatis. Statistisches Bundesamt. URL : https://www.destatis.de/DE/Themen/ Staat/Steuern/Steuereinnahmen/Tabellen/steuerhaushalt-kassenmaessigesteuereinnahmen-vor-steuerverteilung.html.

11. Доходи зведеного бюджету України. Матеріали сайту Міністерства фінансів України. URL : https://index.minfin.com.ua/ua/ finance/budget/cons/income/2019/.

12. Reduktion der Mehrwertsteuer in Deutschland. URL : https://ventopay.com/news/reduktion-der-mehrwertsteuer-von-19-auf-7/.

13. Höchststeuersatz der Einkommensteuer in Deutschland bis 2020. Statista. URL : https://de.statista.com/statistik/daten/studie/38327/umfrage/ entwicklung-des-hoechststeuersatzes-in-deutschland/.

14. Офіційний сайт Finance Business Service. Оподаткування в Німеччині. URL : https://fbs-tax.com/uk/tax-planning/germany/taxation-germany.

15. Борисова М. Податки в Німеччині: багаті й бездітні платять більше. 30.06.2020. URL : https://p.dw.com/p/3eOen.

16. Von Nicolai Kwasniewski, Maria Marquart, Marcel Pauly und Patrick Stotz. Wohin die Agrarsubventionen fließen. 29 May2018. URL : https://www.spiegel.de/wirtschaft/soziales/eu-subventionen-landwirtschafterklaerung-in-karten-a-1210055.html.

17. Buro Reinhardt \& Weckbecker Steuerbereatungsgesellschaft $\mathrm{mbH}$. URL : https://web2.cylex.de/firma-home/reinhardt-_-weckbeckersteuerberatungsgesellschaft-mbh-8106014.html

18. Податковий кодекс України : Закон України. Редакція від 23.12.2020. URL : https://zakon.rada.gov.ua/go/2755-17.

19. Офіційний сайт Міністерства фінансів України. Середня місячна зарплата по регіонах України в 2020 p. URL : https://index. minfin.com.ua/ua/labour/salary/average/. 